\footnotetext{
JURNAL CEMERLANG: Pengabdian pada Masyarakat

P-ISSN 2654-4741 / E-ISSN 2655-7894

Vol. 2, No. 2, Juni 2020, $162-172$

DOI: https://doi.org/10.31540/jpm.v2i2.903

PENERBIT: LP4MK STKIP PGRI LUBUKLINGGAU
}

\title{
PELATIHAN DAN PENDAMPINGAN PENYUSUNAN BAHAN AJAR BAGI GURU PONDOK PESANTREN MAZROILLAH KOTA LUBUKLINGGAU DALAM MENINGKATKAN KUALITAS PEMBELAJARAN
}

\author{
Muhtadin, Satinem, Desti Dwi Sari, Sleng Saputra \\ STKIP PGRI Lubuklinggau, Indonesia \\ Email: muhtadinstkip@gmail.com
}

ABSTRAK

Pengabdian masyarakat merupakan salah satu bagian Tri Dharma Perguruan Tinggi. Pengabdian pada masyarakat bertujuan memberikan motivasi kepada para guru Pondok Pesantren Mazroillah untuk menyusun sendiri bahan ajar sesuai degan kebutuhan peserta didik dan guru yang memiliki kualitas baik. Kegiatan Pengabdian Masyarakat ditujukan kepada para guru di Pondok Pesantren Mazroillah yang terdiri atas: guru bahasa Indonesia, Matematika, Ilmu Pengetahuan Sosial, Sejarah, PPKN, Fisika, Bahasa Inggris, Prakarya, Penjaskesrek, dan BK. Permasalahan utama yang berkaitan dengan persiapan pembelajaran adalah sebagai berikut: 1) mereka tidak terbiasa menghasilkan bahan ajar yang sesuai dengan mata pelajaran yang diampunya; 2) para guru telah disibukkan dengan administrasi persiapan pembelajaran, sehingga mereka tidak ada waktu untuk membuat bahan ajar; 3) para guru sangat menggantungkan kepada sekolah untuk menyediakan buku-buku yang dapat digunakan dalam kegiatan pembelajaran; 4) Ada beberapa kendala yang dihadapi mereka untuk menciptakan bahan ajar, misalnya minimnya buku literatur yang digunakan sebagai rujukan dalam penulisan bahan ajar, minimnya contoh bahan ajar yang relevan dengan kebutuhan guru dan siswa. Hasil yang diperoleh dari kegiatan pengabdian masyarakat ini adalah 1) para guru Memiliki kemauan yang sangat tinggi untuk menghasilkan bahan ajar yang sesuai dengan kebutuhan guru dan siswa; 2) para guru Mampu menghasilkan bahan ajar berbentuk buku yang memiliki kualitas baik seperti buku ajar; 3) Para guru memiliki buku ajar yang sesuai dengan kebutuhan siswa dan guru sebesar 53,33\% dari jumlah keseluruhan yang mengikuti pendampingan yaitu 15 guru yang terdiri atas berbagai bidang studi.

KEYWORDS

Pelatihan dan Pendampingan, Penulisan Bahan Ajar, Kualitas Pembelajaran
ARTICLE HISTORY

Received 05 April 2020

Revised 05 June 2020

Accepted 06 June 2020

CORRESPONDENCE Muhtadin @ muhtadinstkip@gmail.com 


\section{JURNAL CEMERLANG: Pengabdian pada Masyarakat \\ P-ISSN 2654-4741 / E-ISSN 2655-7894 \\ Vol. 2, No. 2, Juni 2020, $162-172$ \\ DOI: https://doi.org/10.31540/jpm.v2i2.903 \\ PENERBIT: LP4MK STKIP PGRI LUBUKLINGGAU}

\section{PENDAHULUAN}

Permasalahan yang dihadapi mitra pengabdian pada masyarakat yaitu minimnya sumber rujukan (literatur) bagi para guru di Pondok Pesantren Mazroillah untuk pelaksanaan proses pembelajaran di kelas. Mereka mengalami kesulitan untuk menciptakan bahan ajar sesuai dengan kebutuhan siswa dan guru. Kesulitan tersebut diakibatkan kurangnya pengetahuan guru mengenai pembuatan bahan ajar, belum pernah dilakukan pelatihan untuk menciptakan bahan ajar. Para guru terbiasa melakukan proses pembelajran dengan menggunakan sumber (rujukan) buku, LKS yang disediakan di sekolah tanpa melengkapinya dengan sumber rujukan yang lainnya. Bahan ajar yang dimaksud menurut Lestari (2013), Dick \& Carey (2005), dan Panen (2011) menyatakan bahwa bahan ajar adalah seperangkat materi pembelajaran yang disusun secara sistematis menunjukkan syarat tertentu dari kompetensi yang akan dikuasai dan mengacu pada kurikulum yang digunakan dalam rangka mencapai standar kompetensi dan kompetensi dasar yang telah ditentukan.

Ketika pelaksanaan pembelajaran berlangsung guru belum menggunakan buku panduan yang sesuai dengan tingkat karakteristik siswa dan materi pembelajaran tidak bersifat kontekstual. Prastowo (2011) menyatakan bahwa kenyataan membuktikan bahwa dalam praktik pembelajaran banyak pendidik yang masih menggunakan bahan ajar yang sudah tersedia tanpa memeriksa kelayakan atau merencanakan, menyiapkan, dan menelusuri sendiri sehingga bahan ajar tidak kontekstual. Materi pembelajaran yang baik hendaknya sesuai dengan lingkungan kehidupan siswa, mereka belajar berdasarkan pada fakta yang terjadi di sekitar tempat mereka belajar. Para siswa harus dihadapkan pada sesuatu yang sifatnya fakta dan sesuai dengan realita yang terjadi. Materi dalam bahan ajar harus sesuai dengan kurikulum yang berlaku.

Namun demikian, Kemendikbud (2008) bahwa kurikulum belum relevan dengan kompetensi yang dibutuhkan. Beban belajar terlalu berat dan terlalu luas sehingga materi kurang mendalam. Guru atau dosen perlu mengembangkan bahan 


\section{JURNAL CEMERLANG: Pengabdian pada Masyarakat \\ P-ISSN 2654-4741 / E-ISSN 2655-7894 \\ Vol. 2, No. 2, Juni 2020, $162-172$ \\ DOI: https://doi.org/10.31540/jpm.v2i2.903 \\ PENERBIT: LP4MK STKIP PGRI LUBUKLINGGAU}

ajar sendiri dengan alasan ketersediaan bahan ajar sesuai dengan tuntutan kurikulum. Tuntutan tersebut saat ini belum bisa dipenuhi oleh para guru, khusunya guru di Pondok Pesantren Mazroillah. Arifin dan Kusrianto (2009) menyatakan bahwa sangat disayangkan jika seorang guru/dosen dalam karirnya tidak pernah membuat bahan ajar sendiri. Sebenarnya produk bahan ajar dapat dihasilkan melalui kegiatan penelitian, salah satu jenis penelitian yang mampu menghasilkan produk adalah jenis penelitian pengembangan. Hal ini dinyatakan oleh Sukmadinata (2008) penelitian dan pengembangan merupakan pendekatan penelitian untuk menghasilkan produk baru atau menyempurnakan produk yang telah ada. Penelitian dan pengembangan adalah "a process used to develop and validate educational products" (Borg and Gall (1983), Pandra \& Mardapi (2017), dan Putra (2011)). Dengan demikian, penelitian pengembangan merupakan metode untuk menghasilkan produk tertentu atau menyempurnakan produk bahan pembelajaran berdasarkan analisis kompetensi.

Para guru saat ini telah berusaha untuk menciptakan bahan ajar sendiri yang sesuai dengan keahlian yang dimilikinya. Namun demikian dalam pelaksanaannya tersebut masih dihadapi kesulitan untuk mendapatkan sumber rujukan untuk penulisan bahan ajar. Perpustakaan sekolah Pondok Pesantren Mazroillah masih berusaha untuk melengkapi sumber rujukan dalam pembuatan bahan ajar. Solusi yang ditawarkan melalui kegiatan PKM dosen adalah sebagai berikut: 1) Memanfaatkan secara maksimal potensi/kemampuan guru di Pondok Pesantren Mazroillah untuk menciptakan bahan ajar yang sesuai dengan kebutuhan guru dan siswa sehingga menarik untuk dibaca oleh pengguna bahan ajar; 2) Memanfaatkan potensi guru di Pondok Pesantren Mazroillah untuk menggunakan bahan ajar yang diciptakannya sesuai dengan kebutuhan guru dan siswa dalam proses belajar mengajar sebagai salah satu pendukung literatur dalam pembelajaran; 3) Menghasilkan bahan ajar yang menarik sesuai dengan kebutuhan guru dan siswa dan sesuai dengan lingkungan kehidupan siswa; 4) melatih dan membiasakan para guru di Pondok Pesantren Mazroillah untuk gemar 


\section{JURNAL CEMERLANG: Pengabdian pada Masyarakat \\ P-ISSN 2654-4741 / E-ISSN 2655-7894 \\ Vol. 2, No. 2, Juni 2020, $162-172$ \\ DOI: https://doi.org/10.31540/jpm.v2i2.903 \\ PENERBIT: LP4MK STKIP PGRI LUBUKLINGGAU}

menulis apapun bentuknya, baik karya ilmiah, nonilmiah, ataupun menulis bahanbahan ajar yang sesuai dengan keahlian yang dimilikinya; 5) menyiapkan para guru di Pondok Pesantren Mazroillah untuk dapat mengikuti hibah penulisan bahan ajar yang diselenggarakan oleh Kemendikbud atau intansi yang terkait dengan pendidikan.

\section{MASALAH}

Masalah yang dihadapi mitra pengabdian pada masyarakat yaitu minimnya sumber rujukan (literatur) bagi para guru di Pondok Pesantren Mazroillah untuk pelaksanaan proses pembelajaran di kelas. Mereka mengalami kesulitan untuk menciptakan bahan ajar sesuai dengan kebutuhan siswa dan guru. Kesulitan tersebut diakibatkan kurangnya pengetahuan guru mengenai pembuatan bahan ajar, belum pernah dilakukan pelatihan untuk menciptakan bahan ajar. Para guru terbiasa melakukan proses pembelajran dengan menggunakan sumber (rujukan) buku, LKS yang disediakkan di sekolah tanpa melengkapinya dengan sumber rujukan yang lainnya.

Ketika pelaksanaan pembelajaran berlangsung guru belum menggunakan buku panduan yang sesuai dengan tingkat karakteristik siswa dan materi pembelajaran tidak bersifat kontekstual. Materi pembelajaran yang baik hendaknya sesuai dengan lingkungan kehidupan siswa, mereka belajar berdasarkan pada fakta yang terjadi di sekitar tempat mereka belajar. Para siswa harus dihadapkan pada sesuatu yang sifatnya fakta dan sesuai dengan realita yang terjadi. Tuntutan materi tersebut saat ini belum bisa dipenuhi oleh para guru di Pondok Pesantren Mazroillah.

\section{METODE}

Penyusunan bahan ajar bagi guru di Pondok Pesanten Lubuklinggau digunakan metode pelatihan dan pendampingan. Pelaksanaaan pengabdian masyarakat menggunakan metode pelatihan dan pendampingan dimulai dari 


\section{JURNAL CEMERLANG: Pengabdian pada Masyarakat \\ P-ISSN 2654-4741 / E-ISSN 2655-7894 \\ Vol. 2, No. 2, Juni 2020, $162-172$ \\ DOI: https://doi.org/10.31540/jpm.v2i2.903 \\ PENERBIT: LP4MK STKIP PGRI LUBUKLINGGAU}

persiapan dan surve, dan dilakukan pelatihan dan pendampingan penulisan bahan ajar yang sesuai dengan analisis kebutuhan. Kegiatan analisis kebutuhan mulai dilaksanakan bulan Desember 2019 sampai dengan Januari 2020 dengan sosialisasi kepada semua guru di Pondok Pesantren Mazroillah. Adapun tahapan kegiatan pelatihan dilaksanakan dengan langkah sebagai berikut:

\section{Analisis Lapangan}

Analisis lapangan dengan cara melakukan peninjauan di Lokasi tempat pengabdian pada Pondok Pesantren Mazroillah. Langkah berikutnya dilakukan diskusi dengan mitra (para guru) yang akan membantu pelaksanaan pengabdian pada Masyarakat.

\section{Sosialisasi Program}

Sosialisasi Program dilaksanakan di Pondok Pesantren Mazroillah kota Lubuklinggau kepada para guru bidang studi: bahasa Indonesia, Matematika, Ilmu Pengetahuan Sosial, Sejarah, PPKN, Fisika, Bahasa Inggris, Prakarya, Penjaskesrek, dan BK, semuanya berjumlah 15 orang.

\section{Koordinasi Team}

Kegiatan koordinasi Team dilakukan untuk menyamakan persepsi antara team dosen yang melakukan pengabdian dengan para guru di Pondok Pesantren Mazroillah Kota Lubuklinggau.

\section{Pelatihan Peserta}

Tim PKM dosen mendata semua guru di Pondok Pesantren Mazroilla yang dilibatkan dalam pelatihan penulisan bahan ajar dan penyampaian materi mengenai cara pembuatan bahan ajar. Selain materi mengenai bahan ajar, peserta juga diberi pelatihan dalam merumuskan bahan ajar yang berkualitas sesuai dengan analisis kebutuhan guru dan siswa.

\section{Pendampingan}

Setelah para guru di Pondok Pesantren Mazroillah berhasil menciptakan bahan ajar sendiri, masih tetap diberikan pendampingan untuk mensosialisasikan bahan ajar yang dihasilkan. 


\section{JURNAL CEMERLANG: Pengabdian pada Masyarakat \\ P-ISSN 2654-4741 / E-ISSN 2655-7894 \\ Vol. 2, No. 2, Juni 2020, $162-172$ \\ DOI: https://doi.org/10.31540/jpm.v2i2.903

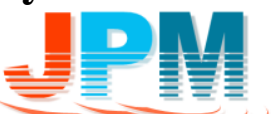 \\ PENERBIT: LP4MK STKIP PGRI LUBUKLINGGAU}

\section{HASIL dan PEMBAHASAN}

Tim PKM melakukan pelatihan dan pendampingan kepada para guru di Pondok Pesantren Mazroillah dengan cara melakukan pertemuan secara rutin. Hasil dari kegiatan PKM diketahui bahwa para guru belum pernah membuat bahan ajar sebelum dilakukan pelatihan dan pendampingan penulisan bahan ajar. Bahan ajar yang digunakan selama ini adalah bahan ajar yang disiapkan oleh pihak sekolah. Mereka juga belum pernah mendapatkan pelatihan mengenai caracara menulis bahan ajar. Kekuatan yang ada mereka memiliki semangat yang sangat tinggi untuk dapat menghasilkan bahan ajar dalam bentuk buku ajar yang sesuai dengan tuntutan siswa dan guru. Mereka bersedia meluangkan waktu untuk dapat menghasilkan buku ajar sesuai dengan kompetensi yang dimilikinya. Kekuatan lain yang mendukung terlaksananya PKM dosen ini bahwa yayasan Pondok Pesantren Mazroillah memberikan motivasi kepada para guru bahwa mereka yang mampu menghasilkan bahan ajar akan diberikan hadiah khusus dari yayasan pondon pesantren.

Berikut ini ditampilkan proses pendampingan penulisan bahan ajar pada para guru di Pondok Pesantren Mazroillah

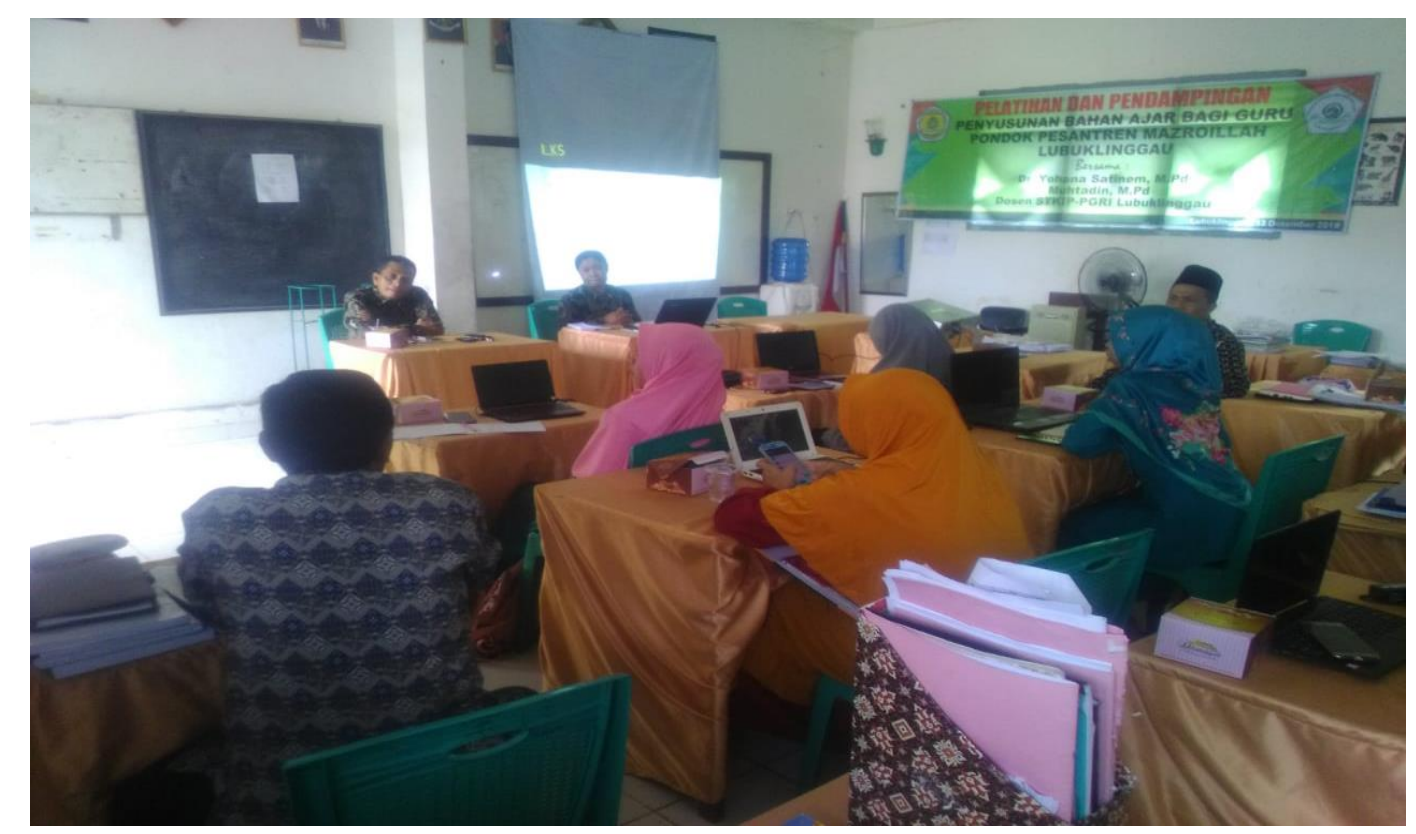

Gambar 1. Pelaksanaan Pelatihan

https://ojs.stkippgri-lubuklinggau.ac.id/index.php/JPM 


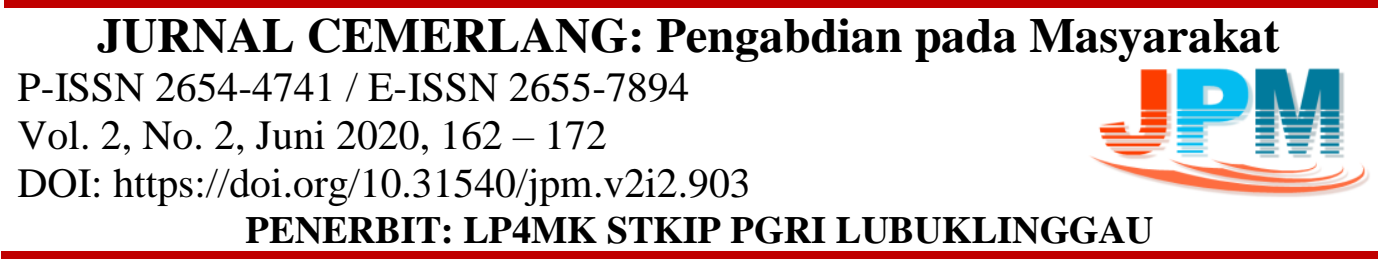

PENERBIT: LP4MK STKIP PGRI LUBUKLINGGAU

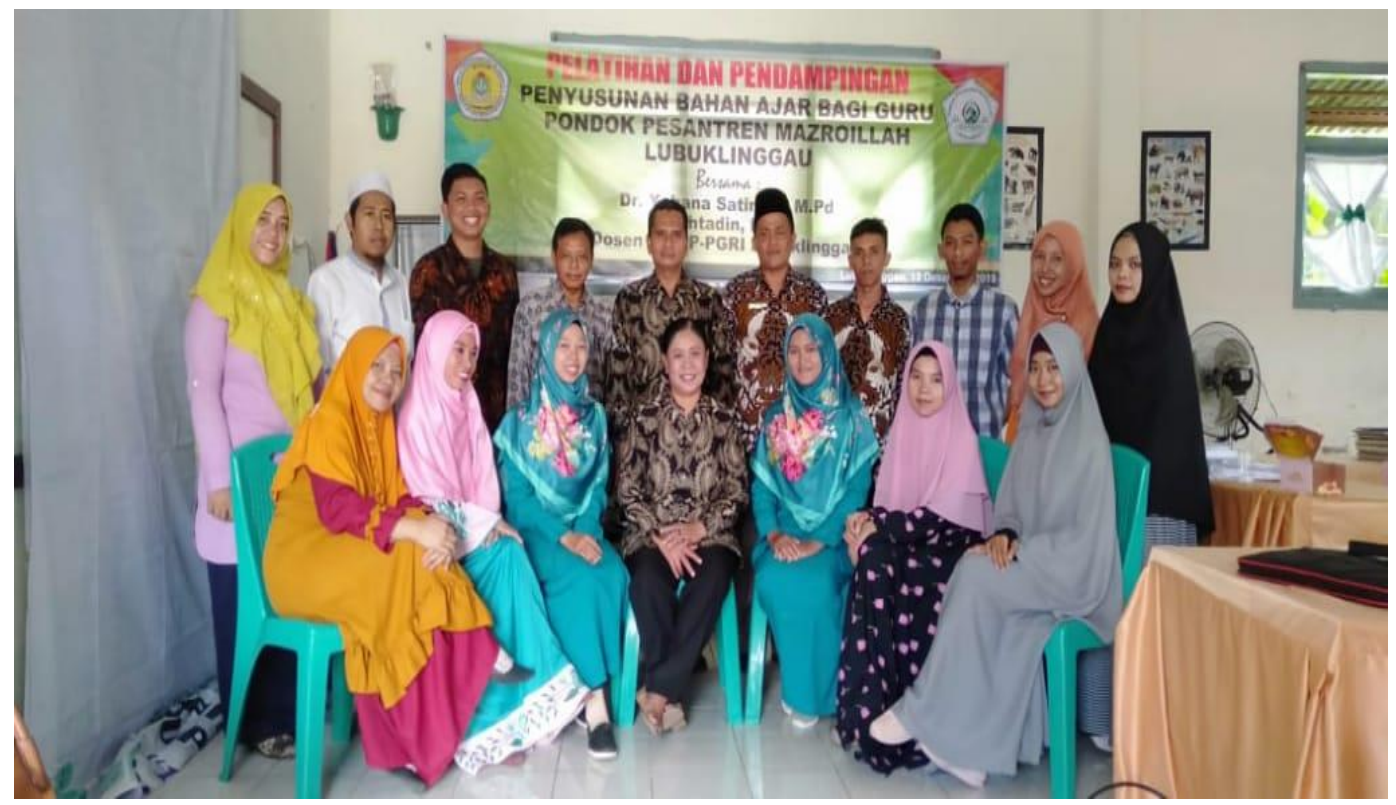

Gambar 2. Tim Pengabdian dan Peserta

Tampak pada gambar aktifitas para guru ketika mengikuti materi pelatihan dan pendampingan penulisan bahan ajar. Pertemuan diawali dengan penyampaian materi mengenai kiat menulis bahan ajar, cara penulisan bahan ajar, dan penggunaan bahan ajar. Rencana awal penulisan bahan ajar yang akan disampaikan dalam PKM berbentuk LKS, namun dalam perkembangannya para guru sepakat untuk menulis bahan ajar dalam bentuk buku ajar. Alasan para guru menentukan bahan ajar berbentuk buku adalah untuk kelengkapan borang akreditasi dan juga sebagai buku pokok dalam pembelajaran sesuai dengan bidang studi masing-masing. Mereka ingin mencoba melaksanakan proses pembelajaran bersumber pada buku yang dihasilkan oleh guru.

Cukup banyak peserta pelatihan yang memberikan tanggapan terhadap materi yang disampaikan oleh tim PKM. Misalnya mereka menanyakan kiat-kiat untuk dapat menghasilkkan bahan ajar yang diminati oleh peserta didik, bagaimana mana menentukan materi pembelajaran yang sesuai dengan SK dan $\mathrm{KD}$, bagaimana menentukan urutan materi pembelajaran, bagaimana desain buku yang menarik minat siswa. Pertayaan yang berikutnya berkaitaan dengan 


\section{JURNAL CEMERLANG: Pengabdian pada Masyarakat \\ P-ISSN 2654-4741 / E-ISSN 2655-7894 \\ Vol. 2, No. 2, Juni 2020, $162-172$ \\ DOI: https://doi.org/10.31540/jpm.v2i2.903 \\ PENERBIT: LP4MK STKIP PGRI LUBUKLINGGAU}

kesediaan validator untuk dapat melakukan validasi terhadap buku ajayang dihasilkan oleh para guru. Pertanyaan terakhir yang sangat mendasar dan juga berupa saran adalah bagaimana cara mendapatkan buku literatur untuk menulis buku ajar yang dihsailkan, apakah STKIP-PGRI Lubuklinggau siap memvalidasai keperluan tersebut.

Semua pertanyaan yang diberikan oleh peserta pelatihan PKM dapat dijawab dengan bijak, bahwa tim PKM akan setia mendapingi sampai bahan ajar siap untuk dicetak. STKIP-PGRI juga bersedia untuk melakukan MOU dengan pondok pesantren Mazroillah dalam hal pemanfaatan perpustakaan bersama. Kecuali itu, lembaga juga siap untuk menyediakan validator bahan ajar, yang terdiri atas: validator kebahasaan, validator materi dn validator desain tanpa dikenakan biaya aprasional.

Beberapa kesulitan yang dialami para guru di Pondok Pesantren Mazroillah dalam penulisan bahan ajar dapat dijelaskan sebagai berikut:

1. Kesulitan merumuskan hasil analisis kebutuhan bahan ajar yang sesuai dengan situasai siswa belajar.

2. Kesulitan untuk menentukan urutan materi pembelajaran dari yang tergolong mudah ke materi yang digolongkan sulit.

3. Minimnya buku literatur yang digunakan sebagai penulisan bahan ajar yang memiliki kualitas seperti layaknya buku ajar yang digunakan selama ini dalam pembelajaran.

4. Minimnya pengetahuan para guru mengenai penulisan bahan ajar yang sesuai dengan kebutuhan guru dan siswa.

5. Kesulitan mengawali proses menulis bahan ajar, mereka bingung bagaimana melakukan penulisan isi buku mulai dari bab I sampai pada bab berikutnya.

6. Kesulitan untuk mendesain bahan ajar yang menarik sesuai dengan yang diinginkan oleh siswa. 


\section{JURNAL CEMERLANG: Pengabdian pada Masyarakat \\ P-ISSN 2654-4741 / E-ISSN 2655-7894 \\ Vol. 2, No. 2, Juni 2020, $162-172$ \\ DOI: https://doi.org/10.31540/jpm.v2i2.903 \\ PENERBIT: LP4MK STKIP PGRI LUBUKLINGGAU}

7. Kesulitan untuk menentukan validator bahan ajar berbentuk buku yang memiliki keahlian sesuai dengan buku ajar yang dihasilkan (terdapat minimal 3 validator bila buku tersebut akan digunakan dalam pembelajaran sebagai literatur) yaitu validator kebahasaan, desain, dan materi.

8. Kesulitan mereka untuk membagi waktu antara mengajar dengan menulis bahan ajar berbentuk buku.

9. Diperlukan waktu yang lama kurang lebih tiga bulan untuk menghasilkan buku ajar yang berkualitas sesuai dengan kebutuhan guru dan siswa.

10. Saat ini masih dalam proses penyelesaian penulisan bahan ajar berbentuk buku oleh para guru di Pondok Pesantren Marzoillah.

Beberapa solusi yang diberikan pada para guru peserta pelatihan penulisan bahan ajar di Pondok Pesantren Mazroillah dalam menghadapi kesulitan penulisan bahan ajar dapat dijelaskan sebagai berikut:

1. Pemateri memberikan cara termudah untuk menuliskan/membagi bab pada isi buku, mulailah dari materi yang mudah dipahami oleh siswa kepada materi yang sulit untuk dipahami.

2. STKIP-PGRI Lubuklinggau memberikan kesempatan dalam bentuk kerja sama dengan lembaga mitra yaitu Pondok Pesantren kota Lubuklinggau dalam hal pemanfaatan perpustakaan dengan fasilitas buku yang sangat lengkap sesuai dengan program studi yang terdpat di STKIP-PGRI Lubuklinggau.

3. Pemateri memberikan contoh bentuk bahan ajar yang dihasilkan oleh dosen yang sesuai dengan kebutuhan siswa dan guru serta sudah memiliki ijin cetak atau ber ISBN.

4. Memberikan motivasi untuk mengawali kegiatan gemar menulis dan membiasakan melakukan kegiatan menulis termasuk menulis buku ajar. Supaya mendapatkan hasil yang baik dalam menulis diperlukan latihan secara terus menerus. 


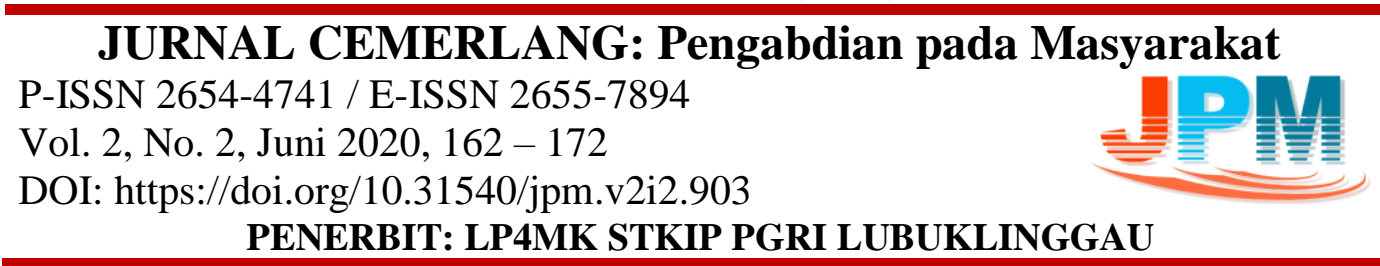

5. STKIP-PGRI Lubuklinggau telah memiliki beberapa doktor yang memiliki keahlian untuk melakukan validasi bahan ajar dan beliau siap untuk membantu para penulis buku ajar atau bahan ajar. Kegiatan validasi yang dilakukan oleh para doktor tidak dikenakan biaya sebagai bukti kepedulian lembaga terhadap sekolah yang dijadikan mitra.

6. Semua validator yang diinginkan oleh para guru dalam penulisan buku ajar yang sesuai dengan kebutuhan siswa dan guru dapat divasilitasi oleh para dosen yang ada di STKIP-PGRI Lubuklinggau.

7. Memberikan motivasi bahwa menulis tidak harus menggunakan waktu khusus, namun di sela-sela kesibukan sebagai guru membiasakan diri untuk menulis berapa pun yang bisa didapat.

8. Penulis yang belum terbiasa untuk melakukan kegiatan menulis memang sulit untuk mengungkapkan idenya dan menuangkannya dalam bentuk tulisan, namun perlu dilakukan latihan secara terus menerus sehingga menulis menjadi suatu kebiasaan.

9. Kegiatan pendampingan penulisan bahan ajar kepada para guru di Pondok Pesantren Mazroillah tetap dilakukan sampai akhirnya diperoleh hasil dalam bentuk buku ajar dengan target capaian sebesar 50\% dari jumlah seluruh peserta pelatihan penulisan bahan ajar.

\section{SIMPULAN}

Setelah dilakukan pelatihan dan pendampingan penulisan bahan ajar kepada para guru di Pondok Pesantren Mazroillah diperoleh simpulan sebagai berikut, Para guru di Pondok Pesantren Mazroillah: 1) Memiliki kemauan yang sangat tinggi untuk menghasilkan bahan ajar yang sesuai dengan kebutuhan guru dan siswa; 2) Mampu menghasilkan bahan ajar berbentuk buku yang memiliki kualitas baik seperti buku ajar; 3) Para guru memiliki buku ajar yang sesuai dengan kebutuhan siswa dan guru sebesar 53,33\% dari jumlah keseluruhan yang mengikuti pendampingan yaitu 15 guru yang terdiri atas berbagai bidang studi. 


\footnotetext{
JURNAL CEMERLANG: Pengabdian pada Masyarakat

P-ISSN 2654-4741 / E-ISSN 2655-7894

Vol. 2, No. 2, Juni 2020, $162-172$

DOI: https://doi.org/10.31540/jpm.v2i2.903

PENERBIT: LP4MK STKIP PGRI LUBUKLINGGAU
}

\section{DAFTAR PUSTAKA}

Arsyad, A. 2011. Media Pembelajaran. Jakarta: PT Raja Grafindo Persada.

Arifin, Syamsul dan Adi Kusrianto. 2009. Sukses Menulis Buku Ajar dan Referensi. Jakarta: Grasindo.

Borg. W.R. \& Gall . 1989. Educational Research: An Introduction. Fiith Edition. New York: Longman.

Departemen Pendidikan Nasional. 2001. Sosialisasi KTSP. Jakarta. Departemen Pendidikan Nasional.

Departemen Pendidikan Nasional 2008. Kurikulum Tingkat Satuan Pendidikan. Jakarta: Depdiknas.

Dick, Walter, Lou Carey, dan James O Carey. (2005). The Sistematic Design of Instruction. Bostom: Pearson.

Koesnandar. 2008. Pengembangan Bahan Ajar Berbasis Web. http//web teknologi pendidikan net/http/teknologi pendidikan net/2008/02/12/ Pengembangan Bahan Ajar Berbasis web.

Lestari, Ika. 2013. Pengembangan Bahan Ajar Berbasis Kompetensi Sesuai dengan Kurikulum Tingkat Satuan Pendidikan. Padang: Akademika Permata.

Pandra, V., \& Mardapi, D. (2017). Development of Mathematics Achievement Test for Third Grade Students at Elementary School in Indonesia. International Electronic Journal of Mathematics Education, 12(3), 769-776.

Pannen, Paulina dan Purwanto. 2011. Penulisan Bahan Ajar. Jakarta: Pusat Antar Universitas untuk Peningkatan dan Pengembangan Aktivitas Instruksional Ditjen Dikti Diknas.

Prastowo, A. 2011. Panduan Kreatif Membuat Bahan Ajar Inovatif. Yogyakarta: Diva Press.

Satinem, S., \& Achmad, H. P. (2015). Teaching Materials Model Folklore in Learning Indonesian Based on Thematik Approach. IJLECR-International Journal of Language Education and Culture Review, 1(2), 27-34.

Satinem, Y. (2016, May). Blog AS Alternatif Media In Teaching Literature. In International Conference on Education and Language (ICEL) (p. 24).

Sukmadinata, Nana Syaodih. 2008. Metode Penelitian Pendidikan. Jakarta: Remaja Rosdakarya. 